\title{
Quantity-of-money fluctuations and economic instability: empirical evidence for the USA $(1958-2006)^{*}$
}

\author{
Panayotis G. Michaelides, ${ }^{* *}$ John G. Milios, Konstantinos N. Konstantakis and \\ Panayiotis Tarnaras \\ National Technical University of Athens, Greece
}

\begin{abstract}
This paper examines the relation between the fluctuations in the quantity of money and the fluctuations in economic activity; that is, the cyclical components of each variable. The principal question posed is: how do the fluctuations in the quantity of money affect or get affected by the fluctuations of output and profitability in the US economy (1958-2006)? Our investigation stops in 2006 as the dynamics of the traditional economic structures changed dramatically in the US and globally after 2006. The empirical results indicate strong cyclical behaviour of most variables. Furthermore, the cyclical components of output/profitability and the quantity of money move in the same direction and there is also a significant relationship between them. A very interesting result is that fluctuations in output/profitability do cause fluctuations in the quantity of money, but fluctuations in the quantity of money do not cause fluctuations in output/profitability, giving priority to a 'macroeconomic' point of view, where overall economic activity, expressed through profitability and output, shapes (but is not shaped by) the quantity of money. Our empirical findings, thus, imply a revision of the usual reading which favours causality running from the quantity of money.
\end{abstract}

Keywords: quantity of money, causality, USA

JEL codes: $B 16, C 13, C 22$

\section{INTRODUCTION}

The so-called quantity theory of money, probably one of the oldest theories in economics, has triggered interesting discussions, in the works of Hume and J.S. Mill among others, but primarily in the research programme of the Austrian School of Economics and that of the Monetarists. Of course, it is also present in the Marxian, (post-)Keynesian and Schumpeterian doctrines. In fact, according to some authors the quantity theory of money dates

* The authors would like to thank the Editors and two anonymous referees for their helpful comments. We would also like to thank Lefteris Tsoulfidis for constructive comments on a previous version of this article.

** Panayotis G. Michaelides, Laboratory of Theoretical \& Applied Economics, School of Applied Mathematics \& Physics, National Technical University of Athens, Greece, Heroon Polytechneiou 9, 157.80, Zografou Campus, Tel: 302107721624; fax: +302107721618, email: pmichael@central. ntua.gr.

Received 21 March 2014, accepted 28 November 2014 
back to sixteenth-century Europe, where gold and silver inflows from the New World into Europe were used in the coinage of money and therefore increased prices. ${ }^{1}$

However, the present paper does not focus on the quantity theory of money, per se. In fact, it deals with the relation between the fluctuations in the quantity of money and the fluctuations in economic activity; that is, the cyclical components of each variable. Analytically, the question posed is: how do the fluctuations in the quantity of money affect or get affected by the fluctuations of output and profitability in the US economy (1958-2006)? Our investigation stops in 2006 as the dynamics of the traditional economic structures changed dramatically in the US and globally after 2006.

The paper is structured as follows: Section 2 sets out the theoretical framework; Section 3 presents a brief review of the literature; Section 4 describes the methodology; Section 5 presents the empirical results; finally, Section 6 concludes.

\section{ENDOGENEITY VS EXOGENEITY: A BRIEF OVERVIEW}

The issue of endogeneity or exogeneity of money shapes a strong debate and most economists seem to have views on either side (Desai 1989). The exogeneity of money mainly dominates the research work of the Monetarists and Neoclassical economists, whereas the endogeneity of money is mainly supported by the post-Keynesians and Marxists and other relevant theoretical traditions.

\subsection{Monetarism and neoclassicism}

Monetarists, led by Friedman (1912-2006), famously claimed that money matters (Friedman 1956) and is responsible for almost every nominal economic phenomenon. In other words, movements in the stock of money determine the market price of a bunch of macroeconomic variables - that is, output, price levels, etc. Friedman also believed that many phases of economic instability noted in US economic history (from the Great Depression of the 1930s to the inflation of the 1970s) could be explained by the fluctuations in the money supply (Tsoulfidis 2007). Actually, Friedman/Schwartz (1963) attempted to demonstrate the exogeneity of money empirically, meaning - roughly speaking - that money supply fluctuations cause nominal output fluctuations. They thus tried to link preceding monetary policy decisions that led to changes in the money supply with economic fluctuations in the US economy.

Monetarist theory illustrates the causal role of money, meaning that changes in money supply are the most significant determinants of nominal output and inflation. ${ }^{2}$ Of course, monetarism has not gained universal acceptance among economists and was doubted by several famous economists (for example, Tobin 1965b; 1970; Kaldor 1970; Temin 1976; etc.).

Neoclassical economic theory regards money as a neutral device that facilitates economic transactions and whose quantity, ceteris paribus, may only influence the level of prices. Moreover, the money supply is considered to be exogenous, meaning that the public authorities, and more precisely the Central Bank, fully control the quantity of money supplied

1. See Arestis/Howells (2002) and the references cited therein.

2. Friedman famously defended exactly this idea of money being brought to the economy by helicopters: 'Let us suppose now that one day a helicopter flies over this community and drops an additional $\$ 1000$ in bills from the sky ... Let us suppose further that everyone is convinced that this is a unique event which will never be repeated' (Friedman 1969: 4-5). 
to the economy, according to the policy objectives that they aim for. For instance, the issue of exogeneity appears in the writings of Irving Fisher (1867-1947) (Tsoulfidis 2007).

Following the neutrality principle, neoclassical theorists suggested a 'dichotomous' conception of two economies: one economy of real magnitudes and another 'nominal' economy of monetary magnitudes. Neoclassical economists believe that rational economic agents are not interested in monetary but in real magnitudes (for example, quantities, relative prices). This affirmation is in accordance with the microeconomic foundations of mainstream economics. Loans and deposits are simply the monetary outcome of rational decisions (or expectations), which aim at spending or saving real magnitudes; that is, certain quantities of goods and services.

\subsection{Post-Keynesianism}

The non-neutrality of money and its significance, not merely as a means of exchange that facilitates transactions but mainly as a store of value which may be held for future transactions and in response to economic uncertainty and future expectations, has been stressed by both Marx and Keynes ${ }^{3}$ (see, for example, Moore 1988: 207ff; Milios et al. 2002).

Further to this, post-Keynesian theorists, following Kaldor's tradition, formulated the conception that in contemporary developed economies based on credit, money is created endogenously (for a compendious presentation of these approaches, see Moore 1988; Rousseas 1992: 65-122; Itoh/Lapavitsas 1999: 207-245; Mollo 1999; Lapavitsas/Saad-Fihlo 2000).

The money-causality direction adopted by the monetarists is inversed, as post-Keynesians state that the major part of the money stock arises for endogenous reasons (Lavoie 1984). ${ }^{4}$ According to the post-Keynesian approach, the origin of money is economic activity itself: in response mainly to investment spending, money is created in the form of credit, which determines the creation of reserves (and in most cases the issuing of fiat money) by the Central Bank. In a different formulation, the money supply is determined by the demand for (credit) money.

These approaches focus on money through its properties. As with the development of the capitalist economy, credit money becomes the main money form, reducing the significance of fiat money. The creation of overdrafts and other forms of credit deposits issued by commercial banks finally determine the Bank's creation of reserves. The post-Keynesian view is summarised by Wray (2002: 9-10):

$[\mathrm{M}]$ ost mainstream theoretical approaches presume that money is under control of the 'monetary authorities' - in theory, if not in practice. ... In contrast, most heterodox economists, including institutionalists, adopt an 'endogenous' money approach ... . Privately issued money (mostly bank deposits today) is issued only on demand, that is, only because someone has deposited cash or is willing to take out a loan. The latter activity has been concisely described by Post Keynesians as 'loans make deposits' because when a bank accepts a borrower's IOU it simultaneously creates a bank deposit. ... The second important point made by Post Keynesians is that 'deposits make reserves', reversing the interpretation of the deposit multiplier.

3. Keynes responded to the question of money endogeneity in an ambiguous way and seemed to give an affirmative response to it only at certain points of his Treatise on Money (1930) and in other works preceding the writing of The General Theory (1936). For a detailed presentation of Keynes's views on this issue, see Moore (1988: 171-204).

4. According to Mason (1980-1981: 239), empiricism seems to have led monetarists to confuse temporal ordering for logical causality. 
However, more recently, a New Consensus has arisen among the so-called New Keynesians and New Classical economists, in an attempt to reconcile the views of both schools of thought into one unified framework.

\subsection{New Neoclassical Synthesis}

The term New Neoclassical Synthesis has been used to define the New Consensus model which tries to draw a parallel with the original neoclassical synthesis that has dominated textbooks in the discipline over decades (Fontana/Passarella 2013). In fact, the New Consensus model claims to be a new synthesis incorporating important elements of each of the apparently irreconcilable traditions of macroeconomic thought (Woodford 2009: 3). Arguably, this is the reason why some authors, such as Goodfriend/King (1997), Dixon (2008) and McCombie/Pike (2013), call it the New Neoclassical Synthesis. Just as the old consensus tried to include both neoclassical and Keynesian elements in its analysis, the New Consensus tries to pull together the micro-foundation and dynamic tools of (New Classical) real business cycle (RBC) models and the work of New Keynesians on the role of labour and product market frictions and on staggered price- and wage-setting (Blanchard 2008).

According to the New Consensus model, long-term inflation is the result of excess aggregate demand. Supply shocks are random, and their average tends to zero, so that they will have a non-lasting impact on inflation. In the short run, there is a trade-off relationship between inflation and unemployment, which disappears, however, in the long run. Supporters of the New Consensus believe that monetary policy could influence the real economy in the short run, as reflected in the IS curve. According to this, investment and production capacity are inversely related with changes in the real interest rate (Lavoie/Kriesler 2007). McCallum (2001) states that economists belonging to the New Consensus have the following five arguments: (i) money is neutral in the long run; (ii) aggregate demand changes cause an expansionary or recessionary output gap; (iii) the economic growth process is influenced by potential GDP; (iv) the inflation rate is influenced largely by inflation expectations; and (v) the interest rate is exogenous in relation to the money supply, but endogenous in relation to other variables, such as the inflation rate or the output gap (monetary policy rule ). $^{5}$

In this context, in the New Consensus model, money is not the main variable that the central bank is targeting, but the one that is being manipulated to make interest rates behave in the way it desires (Romer 2000). In this sense, the post-Keynesian argument that money supply is endogenous and demand-led has been accepted by the New Keynesian economists who argue that the central banks have the power to determine real interest rates (Lavoie 2006). In this vein, from the standpoint of the New Consensus, money is endogenously created, in the sense that the stock of money is a 'residual' based on the demand for money (Arestis/Sawyer 2006b). According to Woodford (2009), monetary policy need not be theoretically identified with the control of the money supply, mainly because where central banks have an explicit commitment to an inflation target, monetary aggregates play little if any role in policy deliberations. The same position has been anticipated by Romer (2000).

In a broader sense, it could be argued that in the New Consensus model the credibility of the monetary authorities play a crucial role, as Rogoff (1985) argued. Accordingly, the behaviour of the monetary authorities must be expressed in the form of a policy rule; that is, a predictable reaction function depending on few economic variables

5. For a detailed analysis of this topic, see Major (2012) and Fontana/Passarella (2013). 
(Fontana/Passarella 2013). The rationale is to anchor the inflation expectations of agents in the medium to long run (see Allsopp/Vines 2000). If the central bank credibly signals its intent to keep inflation low in the future, it is usually argued that it can also reduce current inflation with less cost in terms of output reduction than might otherwise be required (Clarida et al. 1999). A noteworthy corollary is that it is desirable to shift monetary policy decisions from national governments to politically insulated bodies. In particular, argument (iii) on p. 280 entails the rejection of the exogenous supply of money, and the replacement of a money growth rule by a real rate of interest targeting rule (Lavoie 2006).

However, the consensus obviously was not as broad or stable as Blanchard (2008) and others had thought. With the eruption of the US subprime crisis and its transformation into a global economics crisis comparable to the Great Depression, the convergence towards this approach has come under fire from economists inside and outside academia. Buiter (2009: 1) emphatically characterises it as 'a costly waste of time', whereas Krugman (2009) describes it as 'spectacularly useless at best, and positively harmful at worst'.

\section{SELECTED LITERATURE}

The dilemma between the endogenous and the exogenous character of money, described in the previous section, is also present in the empirical literature, as the results of many works seem to shape views on either side. In what follows, we provide a selected review of the empirical literature on the causal relationship between money and real economic variables.

Over approximately the last 5 decades, the investigation of the dynamics between money and other crucial macroeconomic variables has always been a key topic for many researchers around the globe. In fact, since the seminal work of Mundell (1963) and Tobin (1965a) according to which an increase in the exogenous growth rate of money increases the nominal interest rate and velocity of money, but decreases the real interest rate $-\mathrm{a}$ vast empirical literature has emerged trying to assess the interdependencies between money and key macroeconomic variables that dictate real economic activity. Nearly 50 years ago, Karenken/Solow (1963) emphasised the identification and estimation problems associated with drawing causal inferences between money and output. In this vein, they pointed to the fact that one might conclude that monetary policy has no effects at all on economic activity, which would be precisely the opposite of the truth. Probably one of the first sound empirical attempts to investigate the exogeneity of money in the money-income relationship was made by Sims (1972). The results, based on postwar US data, suggested that a statistically significant causal relationship from money to income is evident but that the opposite is not true. This causal relationship was further confirmed by the prominent work of Sims (1980), who considered interwar US data as well.

In a real-business-cycle framework, King/Plosser (1984) examined the causal relationship between money and business cycle fluctuations under the hypotheses of market clearing and rational expectations, using data on the US economy (1953-1978). According to their findings, increased correlation was evident between money and business cycles in real economic activity. Their results were further confirmed by Bernanke (1986) who found evidence of correlation by using an alternative formulation.

In a seminal paper, Bernanke/Blinder (1992) extended the work of Bernanke/Blinder (1988), who provided an IS-LM model that accounted for monetary policy transmission, by empirically testing their model using data on the US economy in the period 1959-1989. According to their findings, money as expressed through the interest rate of the Federal Reserve Bank is informative towards real macroeconomic variables. The same year, 
Friedman/Kuttner (1992) presented empirical evidence based on the US economy that did not indicate a close relationship between money and non-financial economic activity. More precisely, using data from the 1980s sharply weakened the postwar time-series evidence which indicated significant relationships between money and nominal income or between money and real income and prices separately. In fact, when focusing on data from 1970 onward, the authors found no evidence at all.

In a different framework, Friedman/Kuttner (1996) investigated the predictive power of money on real economic activity using US data for the time period 1965-1994. Their empirical findings gave credit to the monetary policy implemented by the Federal Reserve Bank in the US when compared to other countries. In this context, Caporale et al. (1998), using US data on monetary aggregates, output and interest rates, found statistical evidence that monetary aggregates cause output - in a Granger sense - while the opposite did not hold. Nevertheless, their view contradicts the results of Estrella/Mishkin (1997), according to which the empirical relationships between monetary aggregates, nominal income and inflation are not sufficiently strong and stable in the US economy to support an important role for policymaking. On this matter, Friedman (1998) argued that - with some notable exceptions money growth targets have been a visible influence on policy actions when some form of evidence on these relationships seemed to justify it. However, he was of the opinion that a more advanced econometric model incorporating error correction mechanisms might be able to provide stronger evidence of a relationship between money and either output or prices.

More recently, Stock/Watson (2001), utilising a monthly data set on a selected panel of world economies in the time period 1979-1993, examined the relationship between monetary aggregates, output, short-term interest rates and long-term interest rates. According to their findings, monetary variables were causal to output in a bivariate set-up, while in a trivariate set-up the opposite causal relationship seemed to be in place.

To sum up, the empirical literature on the relationship between money and output is inconclusive, often supporting a non-monetarist explanation of economic phenomena, where money is endogenous. Such an explanation is consistent with a passive role for money, casting doubts on the monetary theories of output, which argue that money should have a causal role in the economic system. ${ }^{6}$

\section{METHODOLOGY}

\subsection{Structural breaks}

Following common econometric practice, we start by testing for the existence of structural breaks in the time series employed using the popular Zivot/Andrews (1992) test. The Zivot/Andrews (1992) model endogenises one structural break $\left(T_{b}\right)$ in a time series series $Y_{t}$ as follows:

$$
Y_{t}=\mu+\theta D U_{t}\left(T_{b}\right)+\beta t+\gamma D T_{t}\left(T_{b}\right)+a Y_{t-1}+\sum_{j=1}^{k} c_{j} \Delta Y_{t-j}+e_{t},
$$

where $D U_{t}$ is a sustained dummy variable capturing a shift in the intercept $\mu$, and $D T_{t}$ is another dummy variable representing a break in the trend occurring at time $T_{b}$

6. As we know, Friedman used to argue that money is responsible for almost all economic phenomena: '[c] hanges in the behaviour of the money stock have been closely associated with changes in economic activity' (Friedman/Schwartz 1963: 676). However, according to a famous quotation attributed to Solow (quoted in New School 2010): '[E]verything reminds Milton [Friedman] of the money supply. Well, everything reminds me of sex, but I keep it out of the paper'. 
where $D U_{t}=1$ if $t>T_{b}$ and zero otherwise, and is equal to $\left(t-T_{b}\right)$ if $\left(t>T_{b}\right)$ and zero otherwise. The null hypothesis is rejected if the coefficient $\mu$ is statistically significant.

The above equation, which is referred to as model C by Zivot/Andrews (1992), accommodates the possibility of a change in the intercept as well as a trend break. Model $\mathrm{C}$, in that work, is the least restrictive compared to the other two models; we thus base our empirical investigation on this model. The Zivot/Andrews (1992) test asserts that $T_{b}$ is endogenously estimated, by estimating the above equation sequentially in order to allow for $T_{b}$ to appear in any particular observation with the exception of the first and last observations. The optimal lag length is determined on the basis of the Schwartz Information Criterion (SIC), Akaike Information Criterion (AIC), or t-test.

\subsection{Stationarity}

Now, in order to avoid spurious correlation, we examine the stationarity characteristics of each time series (see Appendix 2). We use the popular augmented Dickey-Fuller methodology (ADF) (Dickey/Fuller 1979). If the results suggest that a time series is non-stationary in levels then de-trending and filtering the data to induce stationarity is recommended and the estimated residuals are the de-trended data series (MacDonald/Kearney 1987).

\subsection{De-trending and filtering}

Next, in order to create the cyclical part of the time series under investigation, we use both the popular Hodrick-Prescott (HP) and Baxter-King (BK) filters, respectively (see Appendix 3). Analytically, the HP filter is a widely used method by which the long-term trend of a series is obtained using actual data. The trend is obtained by minimising the fluctuations of the actual data around it. This method decomposes a series into a trend and a cyclical component. The parameter used for annual data is equal to $\lambda=100$. (Kydland/Prescott 1990; Hodrick/Prescott 1997; Canova 1998).

Another popular method for extracting the business cycle component of macroeconomic time series is the BK filter (Baxter/King 1999), which is based on the idea of extracting a frequency range dictated by economic theory, corresponding to the minimum and maximum frequency of the business cycle. There is widespread agreement that a business cycle lasts between 8 and 32 quarters and the length of the (moving) average is 12 quarters (ibid.). Consequently, these are the values (2 to 8 years) that we use.

\subsection{White noise}

In order to econometrically test whether the cyclical components of the time series under investigation are indeed a cycle and not white noise, we test for autocorrelation by using the Ljung/Box (1978) test (Q-stat), which practically tests the null hypothesis of white noise for a maximum lag length $k$ (see Appendix 4). The alternative hypothesis is that at least one of these autocorrelations is non-zero, so that the series is not white noise. In case the null hypothesis is rejected, then the underlying time series is clearly not white noise and, in this sense, it could be considered to follow a fluctuation pattern. In case of trending time series, we then test its deviations from trend; that is, the residuals from which sample autocorrelations can be computed. As we know, white noise does not permit any temporal dependence and so its autocovariance function is trivially equal to zero for the various lags. The sample autocorrelation function 
measures how a time series is correlated with its own past history. Its graphical illustration is the correlogram.

\subsection{Periodograms}

Here, we investigate the periodicities of business cycles, assuming that the actual fluctuations of the data are chiefly of a periodic character. We are supposing that the presence of periodic elements in the given fluctuations is possible. The length of the period in an economic series may, in general, be variable. Therefore, we understand by the term 'period' the average length of the cycles and the periodogram can assist in finding these average lengths. The period is measured by testing for the maximum values of $R$ in the time frequency (Rudin 1976) (see Appendix 5).

\subsection{Correlation}

Next, the co-movements between the cyclical components of the quantity of money and output/profitability are assessed, using correlation analysis. Furthermore, the cyclical components of output/profitability and the quantity of money are examined to see if they move in the same direction and if there is a significant correlation between them for various leads and lags; that is, indicating the timing pattern (Appendix 6).

\subsection{Cointegration and causality}

Next, we investigate whether the fluctuations in the quantity of money have predictive power for the fluctuations in profitability/output, and vice versa. The concept of causality (Granger 1969) has been widely used. In general, we say that a variable $X$ causes another variable $Y$ if past changes in $X$ help to explain current changes in $Y$ with past changes in $Y$. The general autoregressive model is appropriate for testing Granger causality only if the variables are not cointegrated. Granger (1986) and Engle/Granger (1987) suggested a test based on cointegration and error-correction models. If cointegration is not detected, the autoregressive model is estimated, otherwise the error- correction model needs to be estimated (see Appendix 7). In order to identify the optimal lag length, we use the Final Prediction Error (FPE) criterion. See, among others, Hsiao (1981), Ahking/Miller (1985), Thornton/Batten (1985), Khim/Liew (2004), Gutiérrez et al. (2007) and Hacker/Hatemi (2008). We conduct bi-variate causality tests between:

(i) Quantity of Money (M3) and nominal output (GDP); and

(ii) Quantity of Money (M3) and Profitability (Profit Rate).

\section{EMPIRICAL ANALYSIS}

\subsection{Data and variables}

We apply the methodological framework set out earlier. The data used are on an annual basis and come from the European Commission's Directorate General for Economic and Financial Affairs (AMECO) database and also the Organisation for Economic Co-operation and Development (OECD) database, and cover the period 1958-2009. 
Various economic variables are used. Appendix 2 shows the results of the ADF test regarding the following time series: output $(Y)$; stock of fixed capital $(K)$; wages $(W)$; quantity of money (M3); and profit rate $(\Pi)$ defined as: $\Pi=(Y-W) / K$ (Duménil/Lévy 2002; Milios et al. 2002; Wolff 2003; Mohun 2006).

Given that official data regarding several time series, such as the stock of fixed capital (and, hence, profitability) are not available in quarterly format, we proceed by using annual data that are readily available to us from the aforementioned sources. Our approach is also supported by the fact that the length of the time series at hand is adequate for reliable econometric estimation. Regarding the quantity of money, there is no single 'correct' measure. Instead, there are several measures, the broader of which is M3. It is exactly because of its broad character, expressing the totality of the quantity of money, that it is employed in this study.

The term M3 refers to the monetary aggregate. In fact, M3 in technical terms is equal to the sum of M1, savings deposits (including money market accounts from which no checks can be written), small denomination time deposits, retirement accounts, large time deposits, Eurodollar deposits, dollars held at foreign offices of US banks, and institutional money market funds. Whereas M1 is defined as the sum of the tender that is held outside banks, travellers' checks, checking accounts (but not demand deposits), minus the amount of money in the Federal Reserve float.

\subsection{Result analysis and discussion}

Following standard econometric practice, we begin by testing for structural breaks in our time series data using the Zivot/Andrews (1992) test. In this context, following economic intuition we test for the existence of a structural break around 2007 when the US subprime crisis made its appearance. The results presented in Appendix 1 clearly indicate the existence of a statistically significant structural break in the profit rate in the year 2007, while all the other time series also present the most negative $t$-statistic in the same year. By taking into consideration the fact that after 2007 the remaining observations are too few, from an econometric perspective, we have to end our analysis in 2006; that is, the year before the structural break takes place. After all, during the post2006 era the dynamics of the traditional economic structures are widely hailed to have changed dramatically in the US and globally. As a result, in what follows we focus on the period 1958-2006.

Next, all macroeconomic variables in levels were non-stationary (Appendix 2) and various de-trending approaches were employed. The graphs of the cyclical components are presented in Appendix 3. Also, the results of the analysis based on the correlograms for the various economic variables are shown in Appendix 4. The results of the Ljung/Box (1978) test imply a rejection of the white noise hypothesis for all the de-trended variables. So, the existence of fluctuations is a valid hypothesis from a statistical viewpoint.

The periodograms reveal the periodicity of the cycles and are shown in Appendix 5. The de-trended output seems to follow an 11-year period cycle. Similarly, the de-trended profit rate is characterised by practically the same periodicity; that is, an 11-year period cycle clearly implying that the movements of output and profit rate that characterise the economic conjecture are largely synchronised. Also, the cycles of the money aggregate M3 have an almost identical periodicity; that is, of 12 years. This clearly implies a high degree of synchronisation among these crucial macroeconomic variables that characterise the economic conjecture. Furthermore, as they all follow almost identical cyclical behaviours, one would expect them to be highly correlated with no time lags. 
In fact, Appendix 6 shows the correlation coefficients among the variables examined. We find evidence of high positive correlation between the variables examined. Thus, it could be argued that the cyclical components of output/profitability go hand-in-hand with the quantity of money, in the same direction. Moreover, the timing pattern of the quantity of money indicates that the peak correlations appear at very moderate lags.

Appendix 7 presents the results of the Granger causality tests. It is evident that the fluctuations in output/profitability $d o$ cause fluctuations in the quantity of money, but fluctuations in the quantity of money do not cause fluctuations in output/profitability. This finding is consistent with a passive role for money, casting doubts on those monetary theories of output that argue that money should have a causal role in the economic system.

\section{DISCUSSION AND CONCLUSION}

To sum up, in this paper we first examined the stationarity properties of the various time series and de-trending/filtering was applied. Next, the de-trended/filtered variables were examined to see whether their time pattern could be considered a cycle and spectral analysis was performed. Then, the co-movements between the cyclical components of the quantity of money and output/profitability were assessed. The results indicate a strong cyclical behaviour of most variables. Also, another interesting finding is that our variables exhibit, roughly speaking, a similar pattern characterised by periodicities of 11-12 years, approximately. Next, we assessed the co-movements between the cyclical components of each time series and we found that the cyclical components of output/profitability and the quantity of money move in the same direction and also that there is a significant correlation between them. Furthermore, after the relevant co-integration tests, we conducted bivariate (Granger) causality tests between output/profitability and quantity of money (M3).

In a broader context, we note that fluctuations in the US economy are not very sharp but the slight decrease of output following the first oil crisis is obvious (Figure A1, Appendix 3). The 1990s began with a recession (Basu et al. 2001), whereas between 1997 and 2000 a sharp increase of output took place, often attributed to the so-called 'new economy' period. Regarding the de-trended profit rate (Figures A4 and A9, Appendix 3), it was apparently related to the negative macroeconomic environment of the $1970 \mathrm{~s}^{7}$ and the oil crisis. An upward movement occurred during the 1990s until 1998, reaching its peak in 1997. This rise coincides with the third period of the US economy characterised by a period during which profitability rose, probably as a result of the rapid rise in the productivity of labour.

The main finding of our research is that fluctuations in output/profitability cause fluctuations in the quantity of money, but fluctuations in the quantity of money do not cause fluctuations in output/profitability, giving priority to a macroeconomic point of view, where economic conjecture in the total economy, expressed through profitability and output, shapes the quantity of money, and not vice versa. In fact, our finding is consistent with the work of several major authors who have found that money fluctuations do not cause cyclical movements in economic activity (see, among others, Karenken/Solow 1963;

7. It is argued in the paper that oil shocks are to blame for the USA's output declines in the 1970s. While this cannot be denied, given the USA's industry dependence on foreign energy, other important events such as the economic (inflationary, etc.) impact of the Vietnam war and the demise of Bretton Woods also played a role. We would like to thank an anonymous referee for pointing this out. 
Tobin 1965b; King/Plosser 1984; Bernanke/Blinder 1992; Friedman/Kuttner 1992; 1996; Estrella/Mishkin 1997; Friedman 1998; Stock/Watson 2001). Our empirical findings thus imply a revision of the mainstream belief that the quantity of money is the causal factor.

Our empirical results seem to be reversing the Humean, Monetarist and neoclassical view of the cause and effect linking money and total economic activity. More precisely, in our research, it is the US economy (1958-2006) as a whole that takes the causal role, and thus determines the main features and the mode of evolution of the quantity of money. It is exactly this theoretical paradigm that cannot be traced in the Monetarist and neoclassical approaches.

We are aware of the fact that, generally speaking, 'the issue of exogeneity versus endogeneity is not settled yet and therefore, continues to attract the attention of economists' (Tsoulfidis 2007: 479). However, our empirical findings stress the theoretical importance of a tradition that should probably be traced back, among others, to Barbon, Wicksell and Marx, and later to Schumpeter and Keynes (for example, Moore 1988; Rousseas 1992; Itoh/Lapavitsas 1999; Milios et al. 2002; Wray 2002; Arestis/Sawyer 2006a).

\section{REFERENCES}

Ahking, F.W., Miller, S.M. (1985): The relationship between government deficits, money growth and inflation, in: Journal of Macroeconomics, 7(Fall), 446-467.

Allsopp, C., Vines, D. (2000): The assessment: macroeconomic policy, in: Oxford Review of Economic Policy, 16(4), 1-32.

Arestis, P., Howells, P. (2002): The 1520-1640 ‘Great Inflation': an early case of controversy on the nature of money, in: Journal of Post Keynesian Economics, 24(2), 181-203.

Arestis, P., Sawyer, M. (2006a): A Handbook of Alternative Monetary Economics, Cheltenham, UK and Northampton, MA: Edward Elgar.

Arestis, P., Sawyer, M. (2006b): The nature and role of monetary policy when money is endogenous, in: Cambridge Journal of Economics, 30(6), 847-860.

Basu, S., Fernald, J., Shapiro, M. (2001): Productivity growth in the 1990s: technology, utilization or adjustment?, in: Carnegie-Rochester Conference Series on Public Policy, 55(1), 117-165.

Baxter, M., King, R.G. (1999): Measuring business cycles: approximate band-pass filters for economic time series, in: Review of Economic and Statistics, 81(4), 575-593.

Bernanke B.S. (1986): Alternative explanations of the money-income correlation, in: Brunner, K., Meltzer, A. (eds), Real Business Cycles, Real Exchange Rates and Actual Policies, Carnegie-Rochester Series on Public Policy No 25, Amsterdam: North-Holland, 49-99.

Bernanke, B.S., Blinder, A.S. (1988): Credit money and aggregate demand, in: American Economic Review, 78, 435-439.

Bernanke, B.S., Blinder, A.S. (1992): The federal funds rate and the channels of monetary transmissions, in: American Economic Review, 82, 901-921.

Blanchard, O.J. (2008): The state of macro, National Bureau of Economic Research Working Paper No 14259.

Buiter, W. (2009): The unfortunate uselessness of most 'state of the art' academic monetary economics, in: FT.com, 6 March 2009, URL: http://blogs.ft.com/maverecon/2009/03/theunfortunate-uselessness-of-most-state-of-the-art-academic-monetary-economics/\#axzz3Md2HauZ2 (accessed 22 December 2014).

Canova, F. (1998): Detrending and business cycle facts, in: Journal of Monetary Economics, 41(3), 475-512.

Caporale, G.M., Hassapis, C., Pittis, N. (1998): Unit roots and long-run causality: investigating the relationship between output, money and interest rates, in: Economic Modelling, 15(1), 91-112.

Clarida, R., Galí, J., Gertler, M. (1999): The science of monetary policy: a New Keynesian perspective, in: Journal of Economic Literature, 38, 1661-1707. 
Desai, M. (1989): Endogenous and exogenous money, in: Eatwell, J., Milgate, M., Newman, P. (eds), The New Palgrave: Money, London: Macmillan, 146-147.

Dickey, D.A., Fuller, W.A. (1979): Distribution of the estimates for autoregressive time series with a unit root, in: Journal of the American Statistical Association, 74(366), 427-431.

Dixon, H.D. (2008): New Keynesian macroeconomics, in: Durlauf, S.N., Blume, L.E. (eds), The New Palgrave Dictionary of Economics, 2nd edn, Basingstoke, UK and New York: Palgrave Macmillan, 40-48.

Duménil, G., Lévy, D. (2002): The profit rate: where and how much did it fall? Did it recover? (USA 1948-2000), in: Review of Radical Political Economics, 34(4), 437-461.

Engle, R.F., Granger, C.W.J. (1987): Cointegration and error correction: representation, estimation and testing?, in: Econometrica, 55(2), 143-159.

Estrella, A., Mishkin, F.S. (1997): Is there a role for monetary aggregates in the conduct of monetary policy?, in: Journal of Monetary Economics, 40(2), 279-304.

Fontana, G., Passarella, V.M. (2013): Demand, money and finance within the New Consensus macroeconomics: a critical appraisal, in: 17th Conference of the Research Network Macroeconomics and Macroeconomic Policies (FMM), Berlin, 24-26 October 2013, URL: http://www. marcopassarella.it/wp-content/uploads/FP-article-2013.pdf (accessed 22 December 2014).

Friedman, B.M. (1998): The rise and fall of money growth targets as guidelines for U.S. monetary policy, National Bureau of Economic Research Working Paper No 5465.

Friedman, B.M., Kuttner, K.N. (1992): Money, income, prices and interest rates, in: American Economic Review, 82(3), 472-492.

Friedman, B.M., Kuttner, K.N. (1996): A price target for U.S. monetary policy? Lessons from the experience with money growth targets, in: Brookings Papers on Economic Activity, 27(1), 77-146.

Friedman, M. (1956): The quantity theory of money: a restatement, in: Friedman, M. (ed.), Studies in the Quantity Theory of Money, Chicago: University of Chicago Press, 3-21. (Reprinted in M. Friedman (2005): The Optimum Quantity of Money, New Brunswick, NJ: Transaction Publishers, 51-67.)

Friedman, M. (1969): The Optimum Quantity of Money and Other Essays, Chicago: Macmillan.

Friedman, M., Schwartz, A. (1963), A Monetary History of the United States, 1867-1960, Princeton, NJ: Princeton University Press.

Goodfriend, M., King, R. (1997): The New Neoclassical Synthesis and the role of monetary policy, in: Bernanke, B.S., Rotemberg, J. (eds), NBER Macroeconomics Annual 1997, vol. 12, Cambridge, MA: MIT Press, 231-296.

Granger, C.W.J. (1969): Investigating causal relations by econometric models and cross-spectral methods, in: Econometrica, 37(3), 424-438.

Granger, C.W.J. (1986): Developments in the study of cointegrated economic variables, in: Oxford Bulletin of Economics and Statistics, 48(3), 201-214.

Gutiérrez, C., Souza, R., Teixeira, O. (2007): Selection of optimal lag length in coinegrated VAR models with weak form of common cyclical features, Banko Central de Brasil Working Paper Series No 139.

Hacker, R.S., Hatemi-J, A. (2008): Optimal lag-length choice in stable and unstable VAR models under situations of homoscedasticity and ARCH, in: Journal of Applied Statistics, 35(6), 601-615.

Hodrick, R.J., Prescott, E.C. (1997): Post-war U.S. business cycles: an empirical investigation, in: Journal of Money, Credit, and Banking, 28(4), 1-16.

Hsiao, C. (1981): Autoregressive modelling of Canadian money income data, in: Journal of American Statistical Association, 74(367), 85-106.

Itoh, M., Lapavitsas, C. (1999), Political Economy of Money and Finance, London: Macmillan.

Kaldor, N. (1970), The New Monetarism, in: Lloyds Bank Review, 97, 1-17.

Karenken, J., Solow, R. (1963): Lags in monetary policy, in: Stabilization Policies, Englewood Cliffs, NJ: Prentice Hall, 14-96.

Keynes, J.M. (1930): A Treatise on Money, London: Macmillan.

Keynes, J.M. (1936): The General Theory of Employment, Interest and Money, London: Macmillan.

Khim, V., Liew, S. (2004): Which lag length selection criteria should we employ?, in: Economics Bulletin, 3(33), 1-9. 
King, R.G., Plosser, I.C. (1984): The behavior of money, credit and prices in a real business cycle, National Bureau of Economic Research Working Paper No 853.

Krugman, P. (2009): Lionel Robbins Lecture, Lecture, London School of Economics, 10 June.

Kydland, F.E., Prescott, E.C. (1990): Business cycles: real facts and a monetary myth, in: Federal Reserve Bank of Minneapolis Quarterly Review, 14, 3-18.

Lapavitsas, C., Saad-Fihlo, A. (2000): The supply of credit money and capital accumulation: a critical view of Post-Keynesian analysis, in: Zarembka, P. (ed.), Value, Capitalist Dynamics and Money, Research in Political Economy, vol. 18, New York: Jai Press, 309-334.

Lavoie, M. (1984): The endogenous flow of credit and the post Keynesian theory of money, in: Journal of Economic Issues, 18(3), 771-797.

Lavoie, M. (2006): A Post-Keynesian amendment to the New Consensus on monetary policy, in: Metroeconomica, 57(2), 165-192.

Lavoie, M., Kriesler, P. (2007): The new view on monetary policy: the New Consensus and its PostKeynesian critique, in: Review of Political Economy, 19(3), 387-404.

Ljung, G., Box, G.P.E. (1978): On a measure of lack of fit in time series models, in: Biometrika, 65(2), 297-303.

MacDonald, R., Kearney, C. (1987): On the specification of Granger causality tests using the cointegration methodology, in: Economics Letters, 25(2), 149-153.

Major, A. (2012): Neoliberalism and the new international financial architecture, in: Review of International Political Economy, 19(4), 536-561.

Mason, W.E. (1980-1981): Some negative thoughts on Friedman's positive economic, in: Journal of Post Keynesian Economics, 3(Winter), 235-255.

McCallum, B.T. (2001): Monetary policy analysis in models without money, in: Federal Reserve Bank of St. Louis Review, 83(4), 19-30.

McCombie, J., Pike, M. (2013): No end to the consensus in macroeconomic theory? A methodological inquiry, in: American Journal of Economics and Sociology, 72(2), 497-528.

Milios, I., Dimoulis, D., Economakis, G. (2002), Karl Marx and the Classics, Burlington, VT: Ashgate.

Mohun, S. (2006): Distributive shares in the US economy, 1964-2001, in: Cambridge Journal of Economics, 30(3), 347-370.

Mollo, M.L.R. (1999): The endogeneity of money: Post-Keynesian and Marxian concepts compared, in: Zarembka, P. (ed.), Economic Theory of Capitalism and its Crises, Research in Political Economy, vol. 17, New York: Jai Press, 3-26.

Moore, B.J. (1988): Horizontalists and Verticalists: The Macroeconomics of Credit Money, Cambridge, UK: Cambridge University Press.

Mundell, R. (1963): Inflation and real interest, in: Journal of Political Economy, 71(3), 280-283.

New School (2010): Monetarism, The History of Economic Thought Website, Economics Department, New School, URL: http://homepage.newschool.edu/het//essays/monetarism/monetarism. htm (accessed 14 November 2010).

Rogoff, K. (1985): The optimal degree of commitment to an intermediate target, in: Quarterly Journal of Economics, 100(4), 1169-1190.

Romer, D. (2000): Keynesian macroeconomics without the LM curve, in: Journal of Economic Perspectives, 14(2), 149-169.

Rousseas, S. (1992): Post Keynesian Monetary Economics, Armonk, NY: M.E. Sharpe.

Rudin, W. (1976): Principles of Mathematical Analysis, New York: McGraw-Hill International Edition.

Sims, C. (1972): Money, income and causality, in: American Economic Review, 62(4), 540-552.

Sims, C. (1980): Comparison of interwar and postwar business cycles: monetarism reconsidered, in: American Economic Review, 70(2), 250-257.

Stock, J.H., Watson, M.W. (2001): Forecasting output and inflation: the role of asset prices, National Bureau of Economic Research Working Paper No 8180.

Temin, P. (1976): Did Monetary Forces Cause the Great Depression?, New York: W.W. Norton.

Thornton, D.L., Batten, D.S. (1985): Lag-length selection and tests of Granger causality between money and income, in: Journal of Money Credit and Banking, 17(2), 164-178.

Tobin, J. (1965a): The monetary interpretation of history, in: American Economic Review, 55(3), $464-485$. 
Tobin, J. (1965b): Money and economic growth, in: Econometrica, 33(4), 671-684.

Tobin, J. (1970): Money and income: post hoc ergo propter hoc?, in: Quarterly Journal of Economics, $84(2), 301-317$.

Tsoulfidis, L. (2007): Quantity theory of money, in: International Encyclopaedia of Social Sciences, 2nd edn, London: Macmillan.

Wolff, E. (2003): What's behind the rise in profitability in the US in the 1980s and 1990s?, in: Cambridge Journal of Economics, 27(4), 479-499.

Woodford, M. (2009): Convergence in macroeconomics: elements of the New Synthesis, in: American Journal of Economics: Macroeconomics, 1(1), 267-279.

Wray, L.R. (2002): Monetary policy: an institutionalist approach, Centre for Full Employment and Price Stability Working Papers No 21, February.

Zivot, E., Andrews, D. (1992): Further evidence on the great crash, the oil-price shock, and the unit-root hypothesis, in: Journal of Business and Economic Statistics, 10(3), 251-270.

APPENDIX 1: ZIVOT/ANDREWS STRUCTURAL BREAK TEST AROUND 2007

Table A1 Variables

\begin{tabular}{llcc}
\hline \multicolumn{4}{c}{ Zivot/Andrews structural break test } \\
\hline Period & \multicolumn{3}{c}{ T-statistic } \\
\cline { 2 - 4 } & $Y$ (output) & $\Pi$ (profit rate) & M3 (quantity of money) \\
\hline $1960-2006$ & -0.46 & -3.51 & 0.38 \\
$1960-2007$ & -0.68 & -3.61 & -0.23 \\
$1960-2008$ & -0.54 & -3.59 & 0.93 \\
\hline
\end{tabular}

APPENDIX 2: ADF STATISTICS

Table A2 Variables (original)

\begin{tabular}{lcccc}
\hline \multicolumn{5}{c}{ Augmented Dickey-Fuller test } \\
\hline Variable & LAGS & T-statistic & Probability & Stationary \\
\hline$Y$ & 1 & -0.753585 & 0.8229 & No \\
$K$ & 2 & 1.164560 & 0.9975 & No \\
$W$ & 0 & -1.879211 & 0.3391 & No \\
Profit rate & 1 & -0.764595 & 0.8199 & No \\
M3 & 1 & 2.253547 & 0.9999 & No \\
\hline
\end{tabular}

Note: The ADF test is based on the following regression:

$$
\Delta \mathrm{Y}_{t}=a+b t+\rho Y_{t-1}+\sum_{i=1}^{m} \gamma_{i} \Delta Y_{t-i}+\varepsilon_{t}
$$

where $b=0$ and $\mu=0$ imply a difference stationary model where the $Y$ variable is integrated of degree one $\mathrm{I}(1)$. 
APPENDIX 3: FIGURES OF ECONOMIC FLUCTUATIONS, FILTERS (HP) AND (BK)

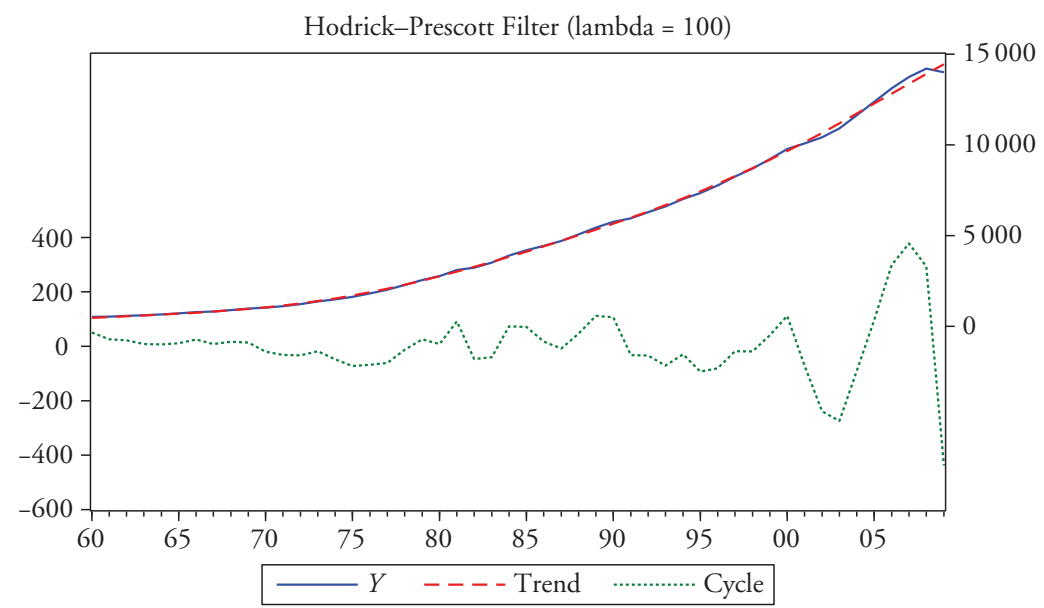

Figure A1 Y (gross domestic product)

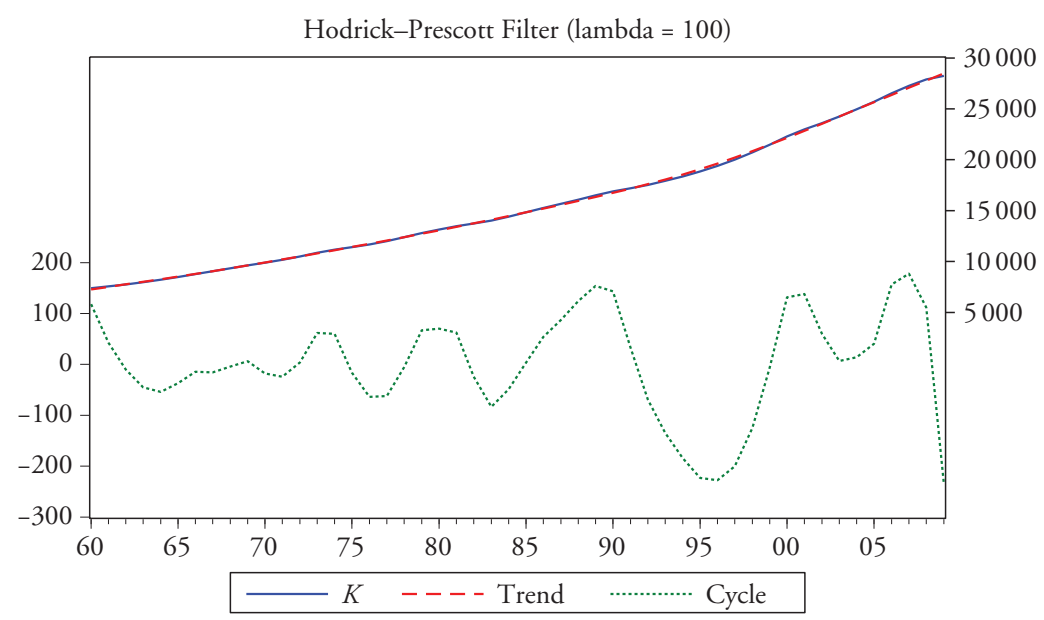

Figure A2 $\mathrm{K}$ (net capital stock) 
292 European Journal of Economics and Economic Policies: Intervention, Vol. 12 No. 3

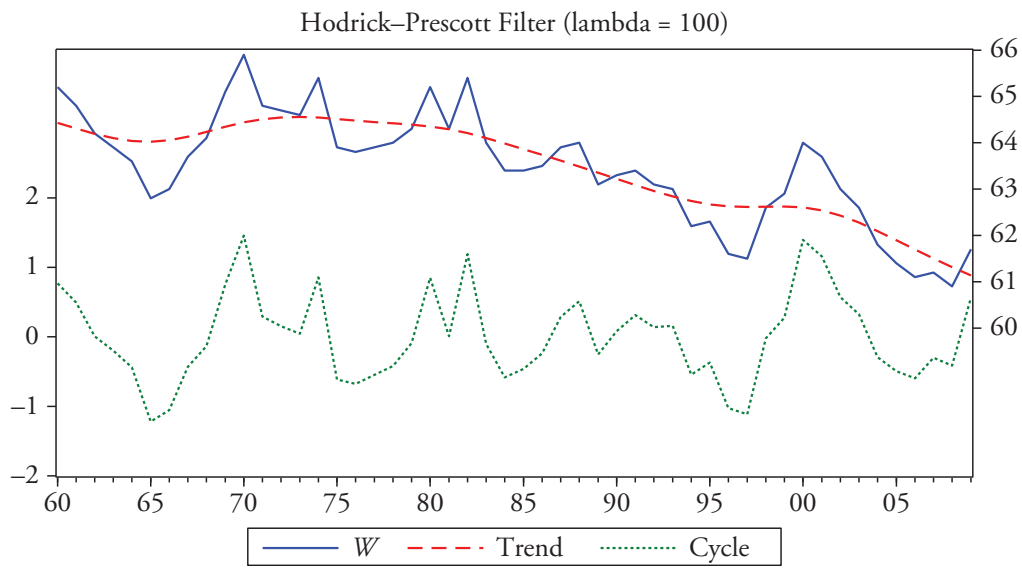

Figure A3 W (wages)

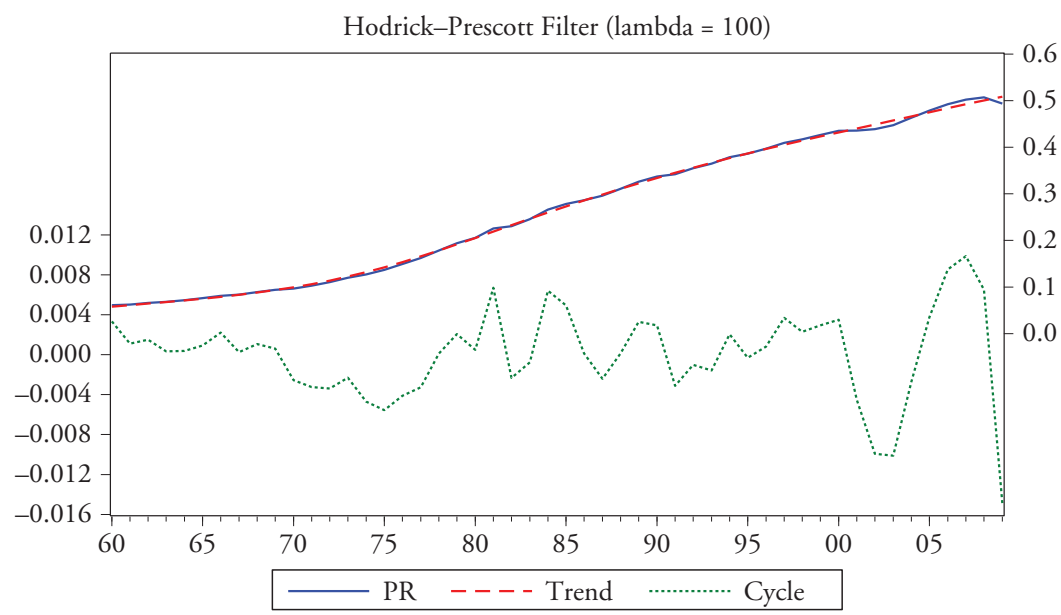

Figure A4 $\Pi$ (Profit rate)

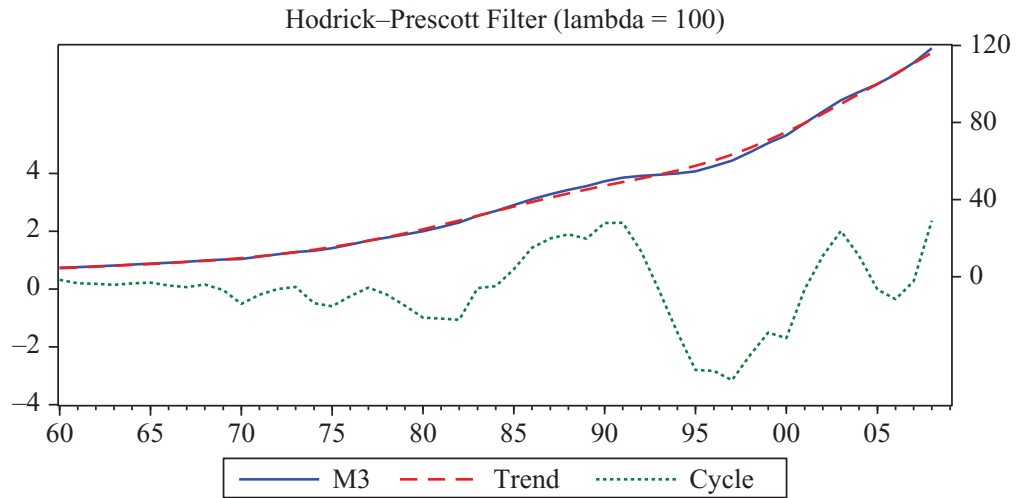

Figure A5 M3 (quantity of money) 


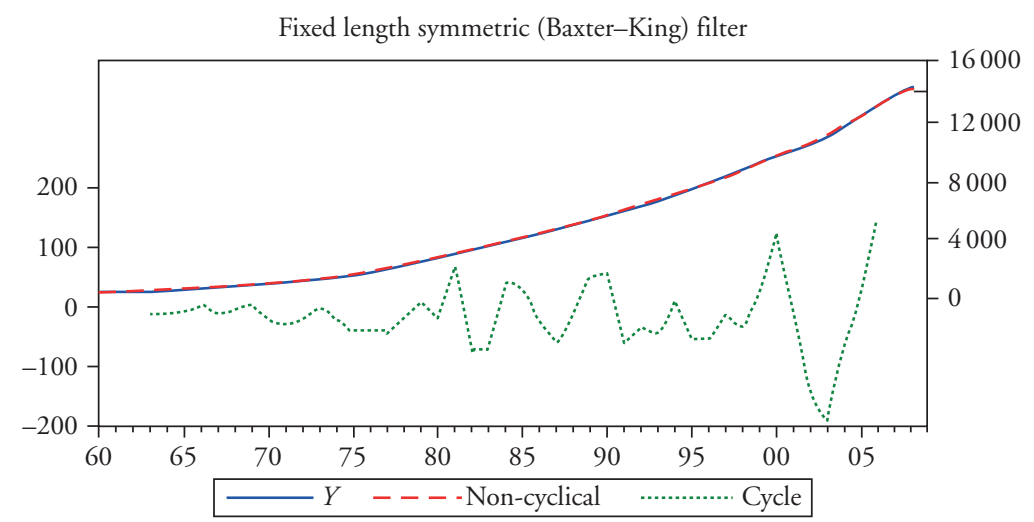

Figure A6 Y (gross domestic product)

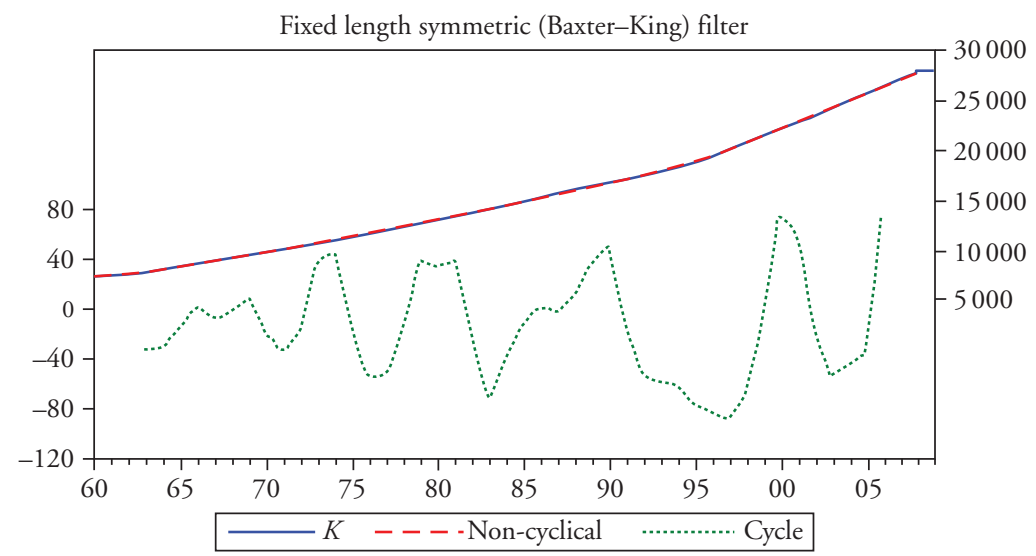

Figure A7 $\mathrm{K}$ (net capital stock)

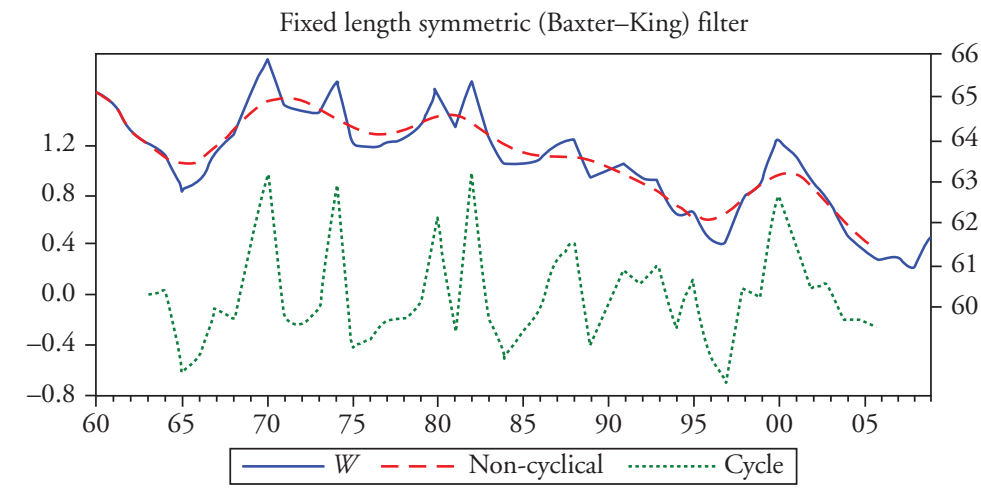

Figure A8 W (wages) 


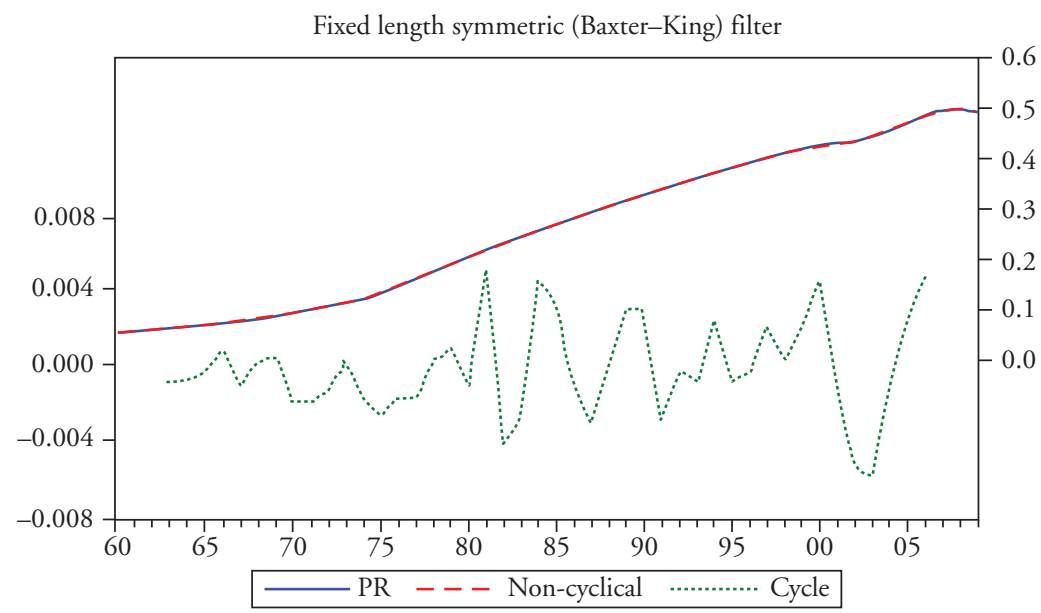

Figure A9 $\Pi$ (profit rate)

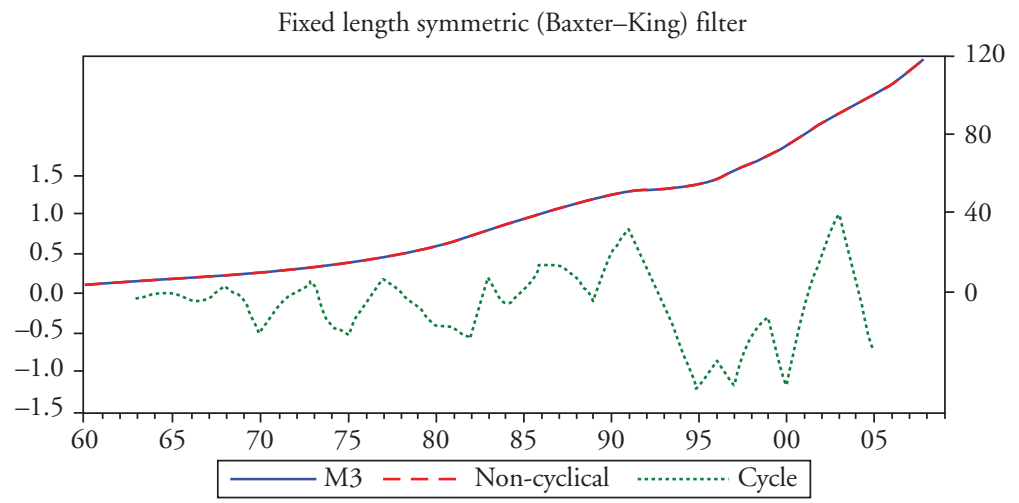

Figure A10 M3 (quantity of money)

Note:

(a) The Hodrick-Prescott Filter The trend is obtained by minimising the fluctuations of the actual data around it; that is, by minimising the following function:

$$
\sum\left[\ln y(t)-\ln y^{*}(t)\right]^{2}-\lambda \sum\left[\left[\ln y^{*}(t+1)-\ln y^{*}(t)\right]-\left[\ln y^{*}(t)-\ln y^{*}(t-1)\right]\right]^{2},
$$

where $y^{*}$ is the long-term trend of the variable $y$ and the coefficient $\lambda>0$ determines the smoothness of the long-term trend.

(b) The Baxter-King Filter The algorithm consists in constructing two low-pass filters, the first passing through the frequency range $\left[0, \omega_{\max }\right]$ (denoted as $\bar{a}(L)$, where $L$ is the lag operator) and the second through the range $\left[0, \omega_{\min }\right]$ (denoted as $\underline{a}(L)$ ). Subtracting these two filters, the ideal frequency response is obtained and the de-trended time series is: $Y^{B P}(t)=[\bar{a}-\underline{a}] y(t)$. 
APPENDIX 4: WHITE NOISE TESTS AND CORRELOGRAMS

Table A3 White noise test for GDP

\begin{tabular}{|c|c|c|c|c|c|c|c|c|}
\hline \multicolumn{9}{|c|}{$Y(\mathrm{GDP})$} \\
\hline \multirow[t]{2}{*}{$\overline{\mathrm{LAG}}$} & \multicolumn{4}{|c|}{ Hodrick-Prescott filter } & \multicolumn{4}{|c|}{ Baxter-King filter } \\
\hline & $\mathrm{AC}$ & PAC & $Q$-Stat & Prob. & $\mathrm{AC}$ & PAC & Q-Stat & Prob. \\
\hline 1 & 0.846 & 0.846 & 37.943 & 0 & 0.295 & 0.295 & 4.0913 & 0.043 \\
\hline 2 & 0.713 & -0.008 & 65.452 & 0 & -0.321 & -0.447 & 9.0655 & 0.011 \\
\hline 3 & 0.6 & -0.002 & 85.366 & 0 & -0.495 & -0.309 & 21.14 & 0 \\
\hline 4 & 0.506 & 0.003 & 99.83 & 0 & -0.056 & 0.115 & 21.3 & 0 \\
\hline 5 & 0.428 & 0.005 & 110.41 & 0 & 0.063 & -0.307 & 21.507 & 0.001 \\
\hline 6 & 0.364 & 0.006 & 118.23 & 0 & -0.006 & -0.172 & 21.509 & 0.001 \\
\hline 7 & 0.311 & 0.007 & 124.1 & 0 & -0.093 & -0.09 & 21.977 & 0.003 \\
\hline 8 & 0.268 & 0.007 & 128.55 & 0 & -0.036 & -0.231 & 22.051 & 0.005 \\
\hline
\end{tabular}

Table A4 White noise test for net capital stock

\begin{tabular}{|c|c|c|c|c|c|c|c|c|}
\hline \multicolumn{9}{|c|}{$K$ (net capital stock) } \\
\hline \multirow[t]{2}{*}{$\overline{\mathrm{LAG}}$} & \multicolumn{4}{|c|}{ Hodrick-Prescott filter } & \multicolumn{4}{|c|}{ Baxter-King filter } \\
\hline & $\mathrm{AC}$ & PAC & Q-Stat & Prob. & $\mathrm{AC}$ & PAC & $Q$-Stat & Prob. \\
\hline 1 & 0.851 & 0.851 & 38.427 & 0 & 0.558 & 0.558 & 14.676 & 0 \\
\hline 2 & 0.721 & -0.012 & 66.582 & 0 & -0.011 & -0.47 & 14.683 & 0.001 \\
\hline 3 & 0.609 & -0.007 & 87.091 & 0 & -0.351 & -0.149 & 20.773 & 0 \\
\hline 4 & 0.514 & -0.002 & 102 & 0 & -0.309 & 0.063 & 25.618 & 0 \\
\hline 5 & 0.434 & 0.002 & 112.87 & 0 & -0.14 & -0.109 & 26.636 & 0 \\
\hline 6 & 0.367 & 0.005 & 120.85 & 0 & -0.094 & -0.218 & 27.105 & 0 \\
\hline 7 & 0.313 & 0.006 & 126.77 & 0 & -0.137 & -0.104 & 28.129 & 0 \\
\hline 8 & 0.268 & 0.005 & 131.22 & 0 & -0.139 & -0.061 & 29.216 & 0 \\
\hline
\end{tabular}

Table A5 White noise test for wages

\begin{tabular}{|c|c|c|c|c|c|c|c|c|}
\hline \multicolumn{9}{|c|}{$W$ (wages) } \\
\hline \multirow[t]{2}{*}{$\overline{\mathrm{LAG}}$} & \multicolumn{4}{|c|}{ Hodrick-Prescott filter } & \multicolumn{4}{|c|}{ Baxter-King filter } \\
\hline & $\mathrm{AC}$ & PAC & Q-Stat & Prob. & $\mathrm{AC}$ & PAC & $Q$-Stat & Prob. \\
\hline 1 & 0.828 & 0.828 & 36.344 & 0 & 0.069 & 0.069 & 0.222 & 0.637 \\
\hline 2 & 0.689 & 0.014 & 62.076 & 0 & -0.083 & -0.088 & 0.5501 & 0.76 \\
\hline 3 & 0.584 & 0.033 & 80.969 & 0 & -0.227 & -0.217 & 3.0862 & 0.379 \\
\hline 4 & 0.508 & 0.041 & 95.553 & 0 & -0.239 & -0.231 & 5.9856 & 0.2 \\
\hline 5 & 0.448 & 0.025 & 107.15 & 0 & -0.075 & -0.106 & 6.2784 & 0.28 \\
\hline 6 & 0.392 & -0.002 & 116.24 & 0 & 0.007 & -0.091 & 6.2812 & 0.392 \\
\hline 7 & 0.337 & -0.017 & 123.09 & 0 & -0.108 & -0.265 & 6.924 & 0.437 \\
\hline 8 & 0.284 & -0.016 & 128.08 & 0 & 0.146 & 0.031 & 8.1296 & 0.421 \\
\hline
\end{tabular}


296 European Journal of Economics and Economic Policies: Intervention, Vol. 12 No. 3

Table A6 White noise test for profit rate

\begin{tabular}{|c|c|c|c|c|c|c|c|c|}
\hline \multicolumn{9}{|c|}{$\Pi$ (profit rate) } \\
\hline \multirow[t]{2}{*}{ LAG } & \multicolumn{4}{|c|}{ Hodrick-Prescott filter } & \multicolumn{4}{|c|}{ Baxter-King filter } \\
\hline & $\mathrm{AC}$ & PAC & Q-Stat & Prob. & $\mathrm{AC}$ & PAC & Q-Stat & Prob. \\
\hline 1 & 0.901 & 0.901 & 43.076 & 0 & 0.201 & 0.201 & 1.8936 & 0.169 \\
\hline 2 & 0.807 & -0.024 & 78.377 & 0 & -0.314 & -0.369 & 6.6534 & 0.036 \\
\hline 3 & 0.719 & -0.023 & 106.97 & 0 & -0.283 & -0.148 & 10.617 & 0.014 \\
\hline 4 & 0.636 & -0.022 & 129.83 & 0 & 0.067 & 0.069 & 10.846 & 0.028 \\
\hline 5 & 0.558 & -0.023 & 147.8 & 0 & 0.134 & -0.042 & 11.775 & 0.038 \\
\hline 6 & 0.484 & -0.023 & 161.65 & 0 & -0.059 & -0.107 & 11.961 & 0.063 \\
\hline 7 & 0.415 & -0.022 & 172.08 & 0 & -0.126 & -0.038 & 12.832 & 0.076 \\
\hline 8 & 0.352 & -0.02 & 179.73 & 0 & 0.036 & 0.048 & 12.905 & 0.115 \\
\hline
\end{tabular}

Table A7 White noise test for quantity of money

\begin{tabular}{|c|c|c|c|c|c|c|c|c|}
\hline \multicolumn{9}{|c|}{ M3 (quantity of money) } \\
\hline \multirow[t]{2}{*}{$\overline{\mathrm{LAG}}$} & \multicolumn{4}{|c|}{ Hodrick-Prescott filter } & \multicolumn{4}{|c|}{ Baxter-King filter } \\
\hline & $\mathrm{AC}$ & PAC & Q-Stat & Prob. & $\mathrm{AC}$ & PAC & Q-Stat & Prob. \\
\hline 1 & 0.593 & 0.777 & 20.056 & 0 & 0.557 & 0.557 & 14.271 & 0 \\
\hline 2 & 0.183 & -0.426 & 22.000 & 0 & 0.15 & -0.232 & 15.328 & 0 \\
\hline 3 & 0.024 & -0.034 & 22.033 & 0.001 & -0.019 & 0.011 & 15.346 & 0.002 \\
\hline 4 & -0.014 & -0.144 & 22.045 & 0.002 & -0.034 & 0.014 & 15.404 & 0.004 \\
\hline 5 & -0.256 & -0.661 & 26.111 & 0.001 & -0.1 & -0.137 & 15.917 & 0.007 \\
\hline 6 & -0.394 & -0.581 & 35.901 & 0 & -0.276 & -0.242 & 19.895 & 0.003 \\
\hline 7 & -0.432 & -0.029 & 47.900 & 0 & -0.243 & 0.077 & 23.081 & 0.002 \\
\hline 8 & -0.313 & 0.761 & 54.345 & 0 & -0.224 & -0.198 & 25.858 & 0.001 \\
\hline
\end{tabular}

Note: In order to test for autocorrelation we use the Ljung/Box (1978) test which tests the null hypothesis of white noise for a maximum lag length $k: Q=n(n+2) \sum_{j=1}^{h} \frac{\hat{\rho}_{j}^{2}}{n-j}$, where $n$ is the sample size, $\hat{\rho}_{j}$ is the sample autocorrelation at $\operatorname{lag} j$, and $h$ is the number of lags being tested.

\section{APPENDIX 5: PERIODOGRAMS}

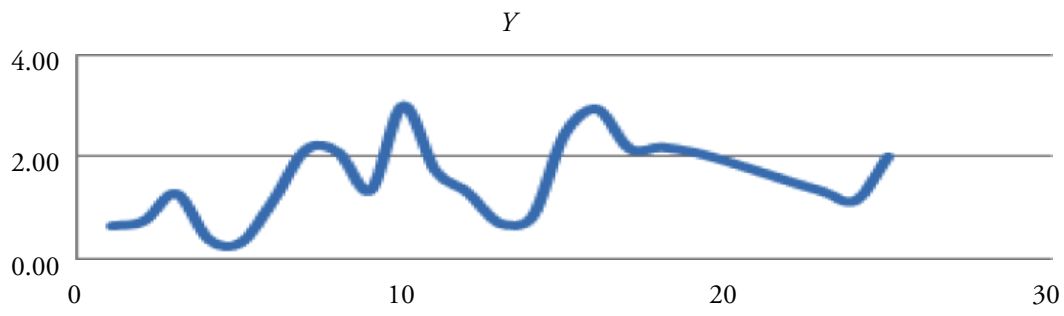

Figure A11 Periodogram of GDP 


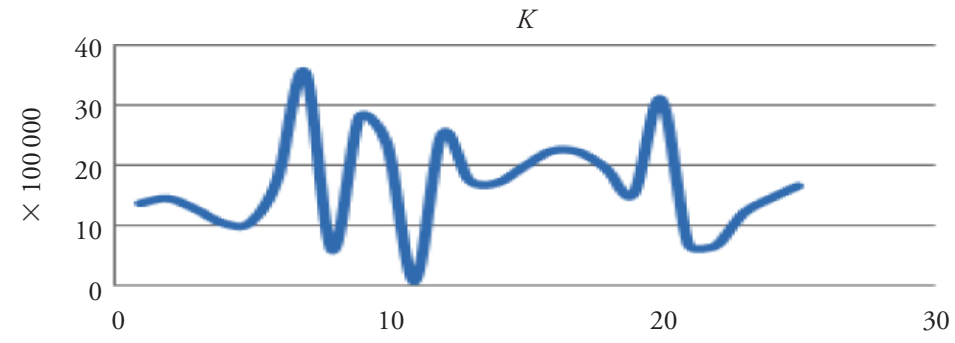

Figure A12 Periodogram of net capital stock

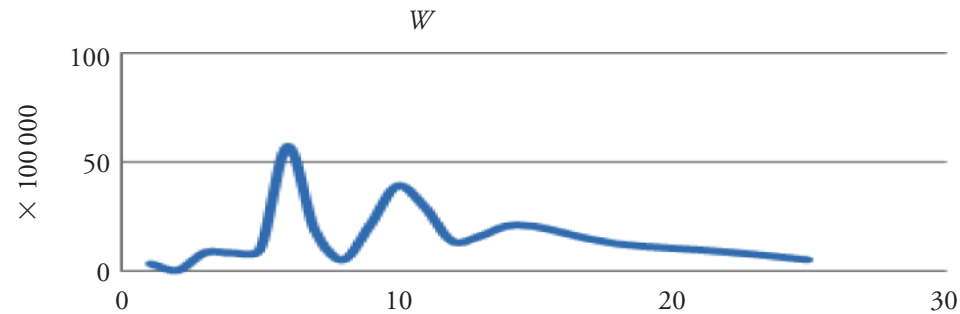

Figure A13 Periodogram of wages

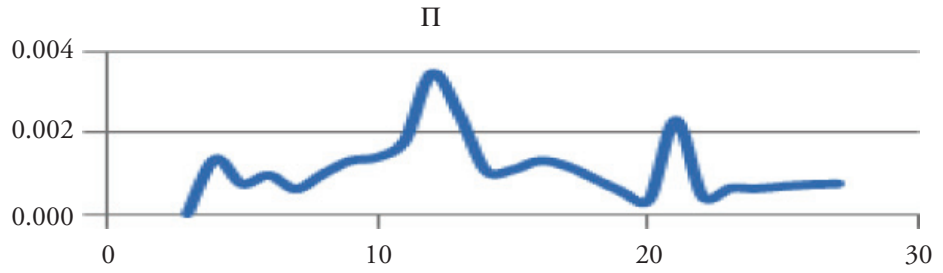

Figure A14 Periodogram of profit rate

M3

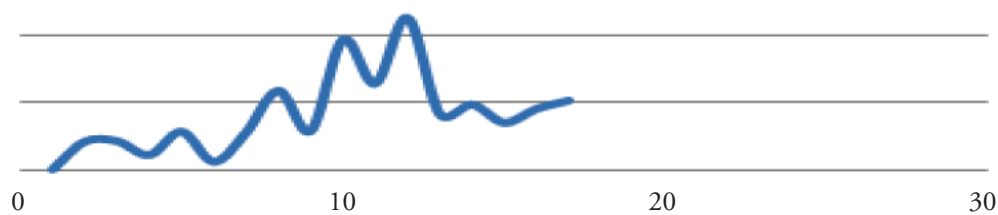

Figure A15 Periodogram of quantity of money 
298 European Journal of Economics and Economic Policies: Intervention, Vol. 12 No. 3

Note: The period is measured by computing the value $R$ in the time frequency:

$$
\begin{aligned}
R_{i}=\sqrt{a_{i}^{2}+b_{i}^{2}}, \alpha_{i}=\frac{2}{n} \sum_{t=1}^{n} X_{t} \cos (2 \pi t / i), b_{i}=\frac{2}{n} \sum_{t=1}^{n} X_{t} \sin (2 \pi t / i), i & =1,2, \ldots m, \\
m & =n / 2,
\end{aligned}
$$

where $a_{i}, b_{i}$ are the coefficients of the Fourier-transformed function $X_{t}$ (Rudin 1976).

\section{APPENDIX 6: CORRELATION}

Table A8 Correlation between GDP and quantity of money

\begin{tabular}{lcc}
\hline & $Y$ and M3 & \\
\hline$i$ & HP & BK \\
\hline 8 & 0.2613 & -0.0737 \\
7 & 0.3093 & -0.0041 \\
6 & 0.3686 & -0.0199 \\
5 & 0.4418 & 0.0025 \\
4 & 0.5318 & 0.1346 \\
3 & 0.6416 & 0.3341 \\
2 & 0.7744 & 0.3664 \\
1 & 0.9326 & -0.1441 \\
0 & 0.9984 & -0.3894 \\
-1 & 0.9265 & -0.069 \\
-2 & 0.7657 & 0.146 \\
-3 & 0.6334 & 0.0701 \\
-4 & 0.5268 & -0.0734 \\
-5 & 0.4425 & -0.0686 \\
-6 & 0.3763 & 0.1393 \\
-7 & 0.3235 & 0.1532 \\
-8 & 0.2799 & 0.0712 \\
\hline
\end{tabular}

Table A9 Correlation between profit rate and quantity of money

\begin{tabular}{lcr}
\hline & $\Pi$ and M3 & \\
\hline$i$ & $\mathrm{HP}$ & $\mathrm{BK}$ \\
\hline 8 & 0.2515 & 0.1226 \\
7 & 0.3045 & 0.2415 \\
6 & 0.3654 & 0.2245 \\
5 & 0.4373 & 0.0219 \\
4 & 0.5234 & -0.0493 \\
3 & 0.6264 & 0.0282 \\
2 & 0.7482 & 0.1113 \\
1 & 0.8902 & -0.0511 \\
\hline & & (continues overleaf)
\end{tabular}


Table A9 Correlation between profit rate and quantity of money (Continued)

\begin{tabular}{lcc}
\hline & $\Pi$ and M3 & \\
\hline$i$ & HP & BK \\
\hline 0 & 0.9669 & -0.3935 \\
-1 & 0.9288 & -0.2832 \\
-2 & 0.8165 & 0.188 \\
-3 & 0.7159 & 0.1587 \\
-4 & 0.6261 & 0.0839 \\
-5 & 0.5459 & 0.0343 \\
-6 & 0.4742 & 0.0714 \\
-7 & 0.4105 & 0.0833 \\
-8 & 0.3543 & -0.0526 \\
\hline
\end{tabular}

\section{APPENDIX 7: COINTEGRATION AND PAIRWISE GRANGER CAUSALITY TESTS}

Table A10 Granger causality test results (error-correction model)

\begin{tabular}{lcccc}
\hline & LAGS & Observations & $F$-Statistic & Probability \\
\hline$Y$ does not Granger cause M3 & 3 & 46 & 13.5857 & 0.000 \\
M3 does not Granger cause $Y$ & 3 & 46 & 0.75962 & 0.524 \\
$\Pi$ does not Granger cause M3 & 10 & 39 & 5.07544 & 0.001 \\
M3 does not Granger cause $\Pi$ & 10 & 39 & 0.53009 & 0.847 \\
\hline
\end{tabular}

Note: The empirical test of Granger causality is based on the following model:

$$
\Delta Y_{t}=a_{0}+\sum_{i-1}^{m} a_{1 i} \Delta Y_{t-i}+\sum_{i=0}^{n} a_{2 i} \Delta X_{t-i}+\lambda \mu_{t-1}+\varepsilon_{t}
$$

where $\Delta$ is the first difference operator, $\Delta Y$ and $\Delta X$ are stationary time series and $\varepsilon_{t}$ is the white noise error term with zero mean and constant variance. Also, $\mu_{t-1}$ is the lagged value of the error term of the cointegration regression: $Y_{t}=c_{1}+c_{2} X_{t}+\mu_{t}$.

Having determined that the series are integrated of order (1), we tested for cointegration. We applied OLS on the latter and examined the residuals for stationarity. The empirical results - which are available upon request by the authors - showed that the residuals were stationary (at the 5\% level) and the series $Y$ and $X$ were cointegrated. Thus, the error correction model had to be estimated. Lastly, in order to identify the optimal lag length we used the FPE criterion, whose values are also available upon request by the authors. 